Determination of Physical Risk Factors in Work Environment of Feed Mills and Evaluation of Occupational Health

\author{
Ali AYBEK ${ }^{1 / D}$, Selçuk ARSLAN ${ }^{2}$ Ali OKUMUŞ3 ${ }^{3}$ \\ ${ }^{1}$ Kahramanmaraş Sütçü İmam University, Faculty of Agriculture, Biosystems Engineering Department, 46100, Kahramanmaraş, ${ }^{2}$ Uludağ \\ University, Faculty of Agriculture, Biosystems Engineering Department,16059, Bursa, ${ }^{3}$ Akel Danışmanlık Ltd. Şti, Kahramanmaraş \\ ${ }^{1}$ https://orcid.org/0000-0003-3036-8204, ${ }^{2}$ https://orcid.org/0000-0003-4636-1234, ${ }^{3}$ https://orcid.org/0000-0002-4615-4932 \\ $\triangle:$ aaybek@ksu.edu.tr
}

\section{ABSTRACT}

The physical risk factors are important for the health and safety of employees, but were not determined up to date. The objective of this study was to ergonomically evaluate the exposure of workers to the physical risk factors (noise, particulate matter (PM), lighting, air temperature, relative humidity, air velocity) in feed mills. The research was carried out in the storage, dosage, and packaging departments of three different feed mills. Noise values were measured with noise meter and PM concentration with a personal sampler using gravimetric method. Lighting, air temperature, relative humidity, and air velocity values were determined using a multi-function measuring device. It was determined that the measured noise exceeded the upper exposure action value (85 dBA) and was very close to the limit value ( $87 \mathrm{dBA})$, PM10 concentration in storage sections exceeded the recommended limit value $(10 \mathrm{mg} \mathrm{m}$ 3), lighting in dosage and packaging sections was below the limit values (1000 lux) in the three departments of the enterprises. Temperature was higher than the recommended values in all departments and also humidity and air velocity values were determined to be insufficient.

\section{Research Article}

\section{Article History}

Received

$: 16.05 .2019$

Accepted $\quad: 30.06 .2019$

Keywords

Feed mills

Physical risk factors,

Occupational health and safety

\title{
Yem Fabrikalarında Çalışma Ortamı Fiziksel Risk Etmenlerinin Belirlenmesi ve İş Sağlığı Açısından
} Değerlendirilmesi

\section{ÖZET}

Fiziksel ortam faktörleri, işletmelerde çalışanların sağlığı ve güvenliği için çok önemli olmakla beraber bugüne kadar bu konuda yeterince çalışılmamıştır. Bu çalışmanın amacı, yem fabrikalarında çalışan işçilerin fiziksel risk faktörlerinden (gürültü, partikül madde, aydınlatma, sıcaklık, bağıl nem, hava hızı) hangi düzeyde etkilendiklerini ergonomik açıdan değerlendirmektir. Araştırma, üç farklı yem fabrikasında, çalışanların mesai boyunca yoğun olarak çalıştığı depo, dozaj ve paketleme bölümlerinde yürütülmüştür. Gürültü değerleri bir gürültü ölçer kullanılarak, PM yoğunlukları kişisel örnekleyici ile gravimetrik yöntem kullanılarak ölçülmüştür. Aydınlatma, hava sıcaklığı, hava bağıl nemi ve hava hızı değerleri ise çok işlevli bir ölçüm cihazı ile belirlenmiştir. İşletmelerin her üç çalışma bölümünde oluşan gürültünün, en yüksek maruziyet eylem değerini (85 dBA) aştığı ve sınır değere (87 dBA) yaklaştığı, PM10 yoğunluğunun depo bölümlerinde önerilen sinır değeri (10 mg ms) aştığı, aydınlatmanın dozaj ve paketleme bölümlerinde sınır değerlerin (1000 lux) altında olduğu belirlenmiştir. Diğer ortam fiziksel faktörlerden sıcaklık değerlerinin tüm çalışma bölümlerinde önerilen değerlerden yüksek olduğu, hava nemi ve akımı değerlerinin ise yetersiz olduğu belirlenmiştir.
Araştırma Makalesi

$\begin{array}{ll}\text { Makale Tarihçesi } \\ \text { Geliş Tarihi } & : 16.05 .2019 \\ \text { Kabul Tarihi } & : 30.06 .2019\end{array}$

Anahtar Kelimeler

Yem fabrikaları

Fiziksel risk etmenleri

İş sağlığı ve güvenliği

To Cite : Aybek A, Arslan S, Okumuş A 2019. Determination of Physical Risk Factors in Work Environment of Feed Mills and Evaluation of Occupational Health. KSU J. Agric Nat 22(Ek Sayl 1): 195-205. DOI: 10.18016/ ksutarimdoga.vi.566547 


\section{INTRODUCTION}

Industrialization has importance as a social phenomenon affecting the development level of countries in many ways, such as employment generation, production of industrial products, and increasing social welfare (Şerefhanoglu Sözen et al. 2008). The agricultural industry is an area in which mutual interaction occurs and integration is required between the agricultural sector and industry sector. The quality and quantity of the products depend on different processes, technologies, equipment, and the services such as preservation, packaging, and marketing. Like in any countries, the agricultural industry has an important place in the economy of Turkey. But, neither production oriented health problems nor safety related issues of the employees have been investigated sufficiently in agriculture and agri-industry (Aybek et al. 2010).

In addition to tackling the issues of safety and health of employees in the plants, to achieve the desired efficiency in plants, work environment conditions (noise, PM, lighting, temperature, humidity, and air speed) should be arranged so as not to threaten the lives of employees. Also, discomfort and distress should not be introduced to the workers and the work environment must be clear of the physical risk factors (Sabanci 2001; Hayta 2007).

The noise, usually at high level, caused by production activities in the work environments adversely affects the health of employees. The exposure is experienced through indirect or direct ways, and sometimes could emerge as irreversible physiological and psychological damages and disorders at the end of the long working periods. Permanent noise induced hearing loss is an occupational disease often encountered among those who work in noisy environments. Furthermore, noisy environments adversely affect the attention of employees or they may cause work accidents, preventing perception of warning signs due to masking effect of noise. The lack of satisfaction in work environments and adverse effects on performance in noisy environments are other aspects that need to be taken into consideration (Wilson and Corlett 1991; Tayyari and Smith 1997; Ege et al. 2003). It was that noise could also cause some physiopathological effects to be revealed. For example, increase in heart rate, reduced digestive system performance, dizziness, reduction in reflex vitality, expansion in pupils, reduction of the electrical conductivity of the skin, increase in the levels of blood cholesterol, increase in hormones in suprarenal gland can be observed (Baspinar and Bayramli 2006).

The exposure to PM is a significant issue for employees. The concerns that organic PM have harmful effects on respiratory symptoms and functions of industrial employees are increasing
(Ahmed et al. 2009). The chemicals and organic PM created in agricultural work environments put employees under the risk (Sprince et al. 2000). The effects of PM on health can vary depending on the source of PM particles, size distribution, concentration, and the duration of exposure (Witney 1988). Production originated dusts are classified as artificial pollutants and adversely affect the air quality thus should not exceed certain limit values (Witney 1988; EU Directive 1999). For example, in case of PM inhalation, respiratory disorders, poisoning and allergic reactions may occur; furthermore, they may cause irritation in the eyes, lungs and skins of employees, and even lung diseases leading likely to death (Matthews and Knight 1971; Witney 1988; Giri et al. 2007; Sabancı and Sümer 2015).

In the works performed in dimly lit environments, eye disorders and accidents were observed resulting in low productivity. Especially insufficient lighting in the environments, in which sensitive work is performed, leads to poor worker performance employees (Ilicak 1988).

The effect of temperature on mental and physical activity starts to be felt from $30{ }^{\circ} \mathrm{C}$. Its effects show themselves as quick fatigue, slow down in thinking process, decrease in thinking capacity, attentional decrease, and therefore increase in the rate of accidents. The sweat glands cannot function enough in hot and humid work environment, which causes workers to experience fatigue, sweating, frequent respiration, acceleration of the heartbeats, flushing, and dizziness (Arıcı 1999). If relative humidity and the ambient temperature are high, sweat evaporation decreases significantly and it becomes difficult to resist the high temperatures. The low relative humidity causes respiratory irritation, chronic cough, and also speech disorders associated with respiratory dehydration (Hayta 2007).

Approximately 500 feed mills are in operation in similar facilities in Turkey with more than 6000 employees working in this agri-industry. The physical work environment factors are not well known in these plants. The aim of this study was to evaluate the physical risk factors at work environment in terms of occupational health including noise, dust, temperature, relative humidity, air speed, and lighting.

\section{MATERIAL and METHOD}

\section{Feed mills}

The research was carried out in the departments (storage, dosage, packaging) of three different feed mills (A, B, C), located in the province of Kahramanmaras, where the employees were generally present during the shift. Some properties of 
the mills are given in Table 1 . The province is situated in Eastern Mediterranean Turkey.

Table 1. Number of employees and capacity of feed mills that were studies

\begin{tabular}{lcc}
\hline Mills & $\begin{array}{c}\text { Number of } \\
\text { workers }\end{array}$ & $\begin{array}{l}\text { Capacity } \\
\text { (ton day }{ }^{-1} \text { ) }\end{array}$ \\
\hline A & 17 & 60 \\
B & 14 & 45 \\
C & 12 & 40 \\
\hline
\end{tabular}

\section{The equipment used in measurements}

An audiometer (Brüel and Kjaer 2250) was used to measure the sound pressure levels. The calibration of the audiometer was done by using a calibrator (Brüel and Kjaer 4231). The PM concentration levels were measured with a personal PM sampler (Sioutas) attached to the employee's collar, equipped with teflon filters. The weight of the filters were measured before and after collecting the PM samples using a microbalance with $\pm 0.1 \mu \mathrm{g}$ resolution (Metler-Toledo UMX2) to determine the dust exposure of the workers using the gravimetric method. In each production department of the feed mills, ambient air temperature, relative humidity, air speed, and lighting were measured with a multifunction measuring device (Testo 435-2).

\section{Conditioning chamber}

PM concentration levels were determined gravimetrically using the sampling header filters. Filters were conditioned in a conditioning chamber at ambient air temperature and relative humidity values of $20{ }^{\circ} \mathrm{C}$ and $50 \%$, respectively for $48 \mathrm{~h}$ before and after collecting the dust samples.

\section{Data collection}

The measurements were taken in the storage (A), dosage (B), and packaging (C) departments of three mills. The exposure to noise was measured with the audiometer, at $1 / 3$ octave band at frequencies from $12.5 \mathrm{~Hz}$ to $20 \mathrm{kHz}$ and the resulting A-weighted equivalent sound pressure levels (LAeq) were reported. The measurements were done at about $1 \mathrm{~m}$ from the ear level of employees (TS EN ISO 9612 2009; TS 2607 ISO 1999).

The size fractionized PM concentrations (PM10, PM2.5, and PM1) were determined in the study. The filters were conditioned for 48 hours at a temperature of $20 \pm 1{ }^{\circ} \mathrm{C}$ and a relative humidity of $\% 50 \pm 5$. PM concentration was calculated using Equation 1:

$$
P M=\frac{1000 *\left(W_{d}-W_{b}\right)}{Q^{*} t}
$$

where;

$\mathrm{PM}$ : particulate matter density $\left(\mu \mathrm{g} \mathrm{m}^{-3}\right)$
$\mathrm{W}_{\mathrm{d}}$ : full filter mass $(\mu \mathrm{g})$

$\mathrm{W}_{\mathrm{b}}:$ empty filter mass $(\mu \mathrm{g})$

Q : pump flow rate $\left(\mathrm{L} \mathrm{min}^{-1}\right)$

$\mathrm{t} \quad$ : working time (min)

Air temperature $\left({ }^{\circ} \mathrm{C}\right)$, relative humidity (\%), air velocity $\left(\mathrm{m} \mathrm{s}^{-1}\right)$, and illumination (lux) values were measured at 5 minute intervals, resulting in a total of 70 to 84 measurements for each physical factor during 6 to 8 hours of work a day. The data for air temperature, $\mathrm{RH}$, air speed, and lighting were processed to find average, standard deviation, standard error, minimum, and maximum values. The calculated values were compared to the recommended limit values. The statistical differences among the departments of each feed mill were determined with Tukey test.

\section{RESULTS and DISCUSSION}

The research findings were analyzed under two subsections. In the first sub-section, all measured physical factors were evaluated for all departments of the feed mills. In the second sub-section, the physical environment factors of the mills were compared statistically.

Evaluation of all measured physical factors among the departments

Noise

The variations of the sound pressure levels are given in Figure 1 as function of frequencies in the feed mills storage. The sound pressure levels first increased from low frequencies to mid-level frequencies in the departments of the feed mills and then levelled out at about $500-4000 \mathrm{~Hz}$ with little decrease with increasing frequencies. Finally the sound pressure levels started dropping as the frequency increased from about 5000 to $20000 \mathrm{~Hz}$. The sound pressure levels at a frequency of $4000 \mathrm{~Hz}$, at which human's ear is known to be the most sensitive to noise, varied between 68 and $73 \mathrm{dBA}$ (Figure 1).

A-weighted equivalent sound pressure levels were found to be $85 \mathrm{dBA}, 84 \mathrm{dBA}$, and $86 \mathrm{dBA}$ respectively in storage, dosage, and packaging departments (Figure 2). The A-weighted equivalent sound pressure levels at storage and packaging departments were found to be 78 and $84 \mathrm{dBA}$ in a previous study (Aybek and Arslan 2005) and $84 \mathrm{dBA}$ in the dosage department (Için 2011).

According to the regulation, the lowest exposure action value is $80 \mathrm{dBA}$, the highest exposure action value is $85 \mathrm{dBA}$, and exposure limit value is $87 \mathrm{dBA}$ (EU Directive 2003). Accordingly, the measured Aweighted equivalent sound pressure levels at the storage and packaging departments ( $85 \mathrm{dBA}$ to 86 $\mathrm{dBA})$ exceeded the highest exposure action value (85 
dBA). Regarding the dosage section (84 dBA), Aweighted equivalent sound pressure levels exceeded the lowest exposure action value ( $80 \mathrm{dBA})$.

As a conclusion, the noise pressure levels should be reduced in the feed mills. Periodic maintenance of the equipment might help reducing the personal noise exposure. The noise intensity at the source can be reduced through provision of technological tools by masking or reducing the noise of the machine components. In cases the noise level exceeds the lowest exposure action value, personal protective equipment (earlaps, earplugs) must be used by the workers. According to the regulation, employers should keep ready ear protective equipment for use of employees, and inform and train the employees on safety issues (EU Directive 2003). The workers should be given protective equipment, especially in the storage and packaging departments of the feed mills since the measured sound pressure levels were at or above the exposure action value.

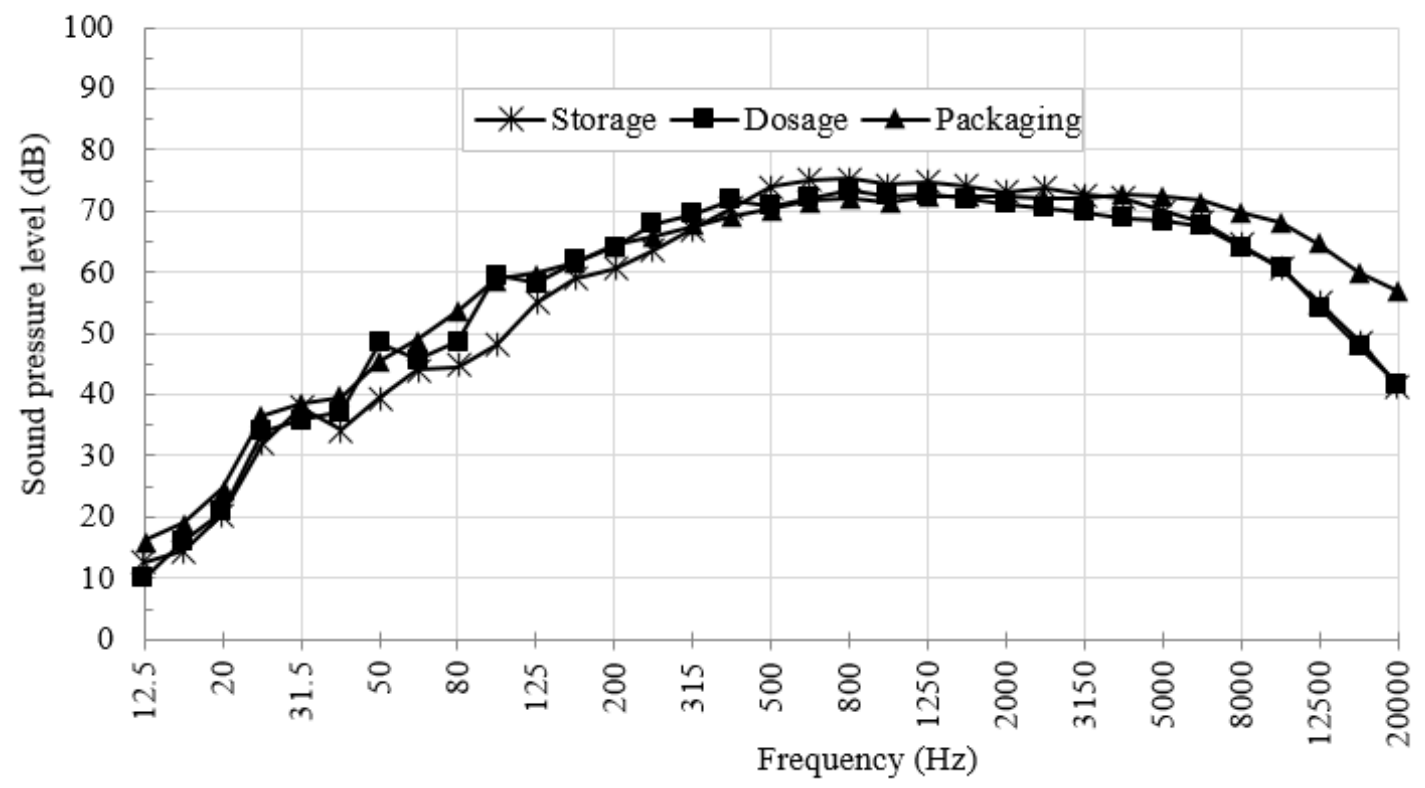

Figure 1. Sound pressure levels as a function of frequency spectrum in different working sections of feed mills

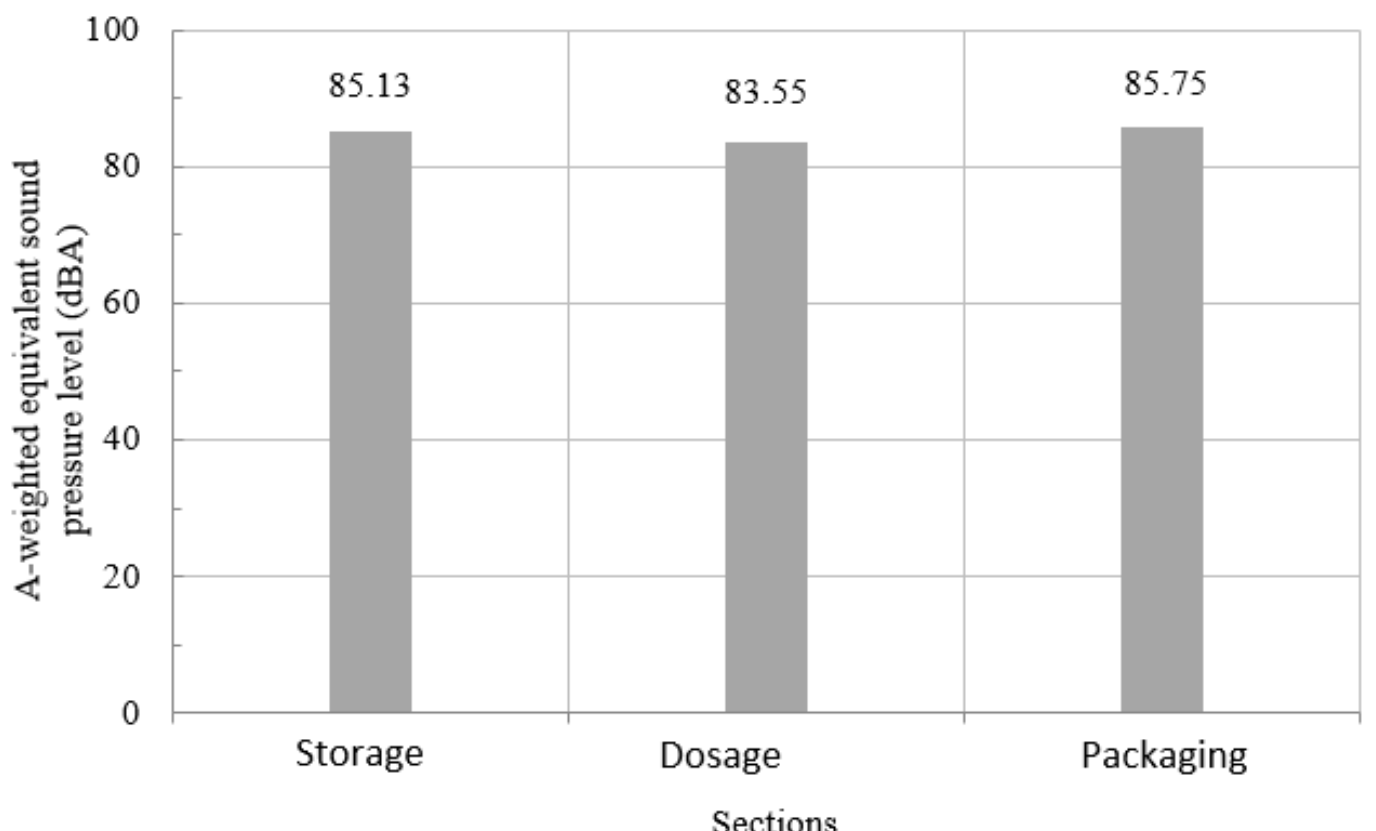

Figure 2. A-weighted equivalent sound pressure levels in working sections of feed mills

\section{Particulate Matter}

The highest and lowest PM10, PM2.5, and PM1 concentrations were found in the storage and packaging sections, respectively (Figure 3). PM10 concentrations were above $2500 \mu \mathrm{g} \mathrm{m}^{-3}$ in the storage and above $1000 \mu \mathrm{g} \mathrm{m}^{-3}$ in the dosage departments. 
Aybek et al. (2010) found greater concentrations in feed mills for all PM fractions in a previous study. The daily-accepted limit for PM10 concentration value in EU countries is $2500 \mu \mathrm{g} \mathrm{m}^{-3}$. Thus, PM10 concentrations in storages of feed mills exceed the limit value. PM2.5 and PM1 concentrations in the other sections of the feed mills were below the limit value.

Based on PM measurements, it could be argued that hazard was present for workers for upper respiratory disturbances and diseases. The generation of dusts during handling of the feed materials should be reduced by technical solutions or the workers should use dust masks to reduce the exposure to coarse particulate matter. Fine particles (PM2.5) did not pose health hazards in different sections of the feed mills.

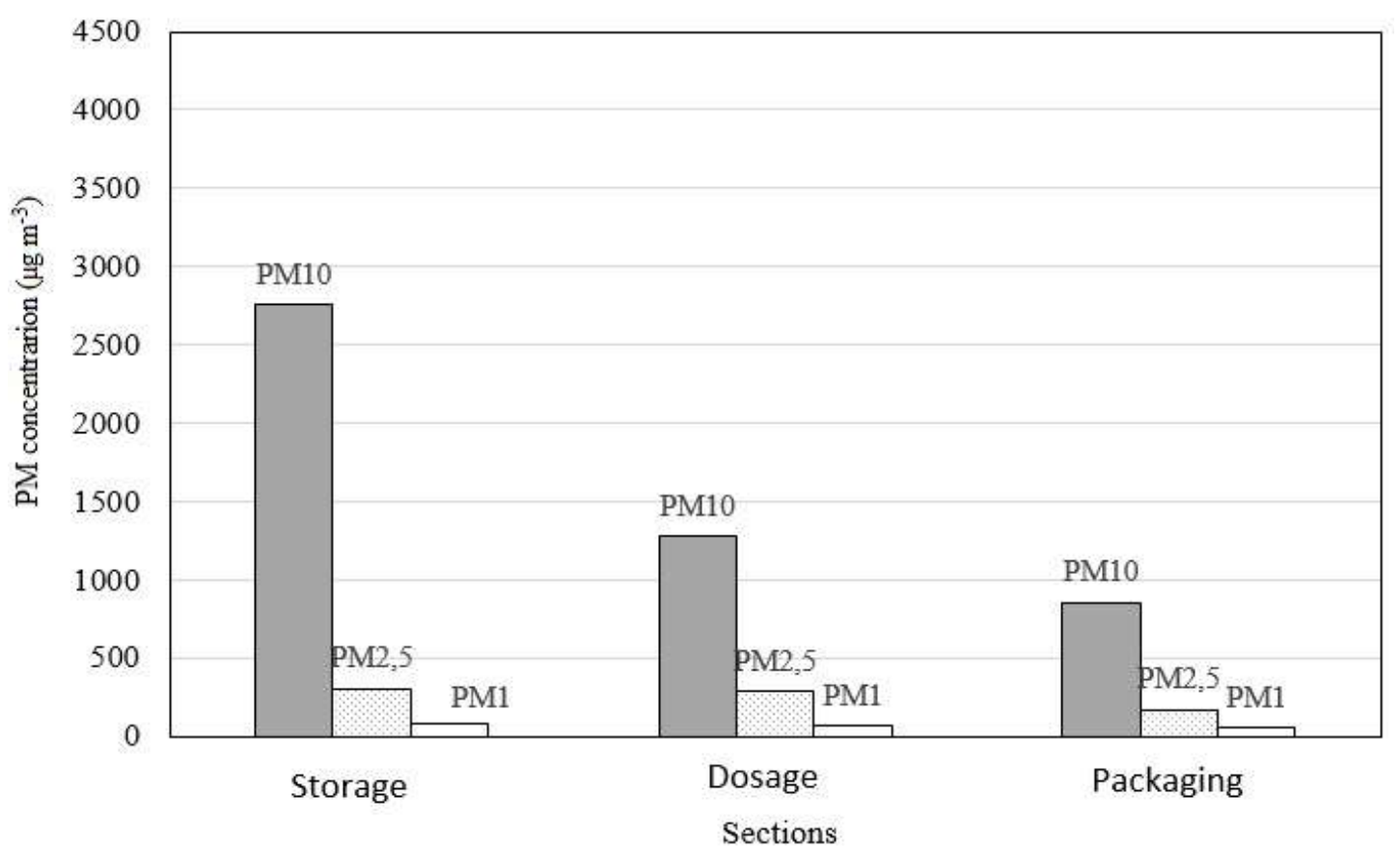

Figure 3. Average concentrations of PM in working sections of feed mills

\section{Lighting}

The average lighting values in storage, dosage and packaging departments of the mills were 103, 80 and 85 lux, respectively (Figure 4). The recommended lighting values for better worker performance are 50 to 200 lux for storage department and 200 to 250 lux for packaging department (Babalik 2007). While lighting at storage departments was within the limits, it was insufficient in the dosage and packaging departments. The lighting systems were not used during day time in the mills and resulted in poor lighting in dosage and packaging departments. Therefore, artificial lighting should be used to improve the lighting conditions, especially in the dosage and packaging departments in the feed mills.

\section{Air temperature}

The mean temperatures were above $30{ }^{\circ} \mathrm{C}$ in all sections of the feed mills. As shown in Figure 5, the temperatures were close to $28^{\circ} \mathrm{C}$ even in the first two hours of the 8 -h shift. The temperature reached $30{ }^{\circ} \mathrm{C}$ around 11:00 am, resulting eventually in high mean temperatures for an 8 hour shift. The maximum temperatures ranged from 32 to $36.2{ }^{\circ} \mathrm{C}$ in the three sections. The lowest air temperature was measured in the packaging section of the mill $\mathrm{C}\left(24.1^{\circ} \mathrm{C}\right)$. When all sections were evaluated, the minimum temperatures ranged from 24.1 to $28.9{ }^{\circ} \mathrm{C}$, suggesting that the workers experienced thermal comfort when the temperatures were at the minimum measured values, corresponding to early working hours of the day. Thus, the temperature needs to be controlled in the work environment for the thermal comfort of workers, especially at noon and afternoon. The average air temperatures measured during the working hours in storage, dosage, and packaging departments were 31.5, 30.9, and $30.6{ }^{\circ} \mathrm{C}$, respectively (Figure 5). However, the temperature varied significantly during the day in the feed mills. Generally, the temperature gradually rose from morning hours and increased during the day in all departments. This research was carried out in June and August. In the research conducted by Aybek et al. (2010) in May and June, the average temperature was $23.4{ }^{\circ} \mathrm{C}$ in the storage department, $16.9{ }^{\circ} \mathrm{C}$ in dosage department, and 20.6 ${ }^{\circ} \mathrm{C}$ in packaging department. When thermal comfort zone of employees is considered between 22 and $29{ }^{\circ} \mathrm{C}$ (Suggs 1991), the temperature values of the three sections were not appropriate. The Mediterranean 
region is usually hot and humid, resulting in discomfort for the workers in the late spring and summer months. The storage, dosage, and packaging sections were not air-conditioned. There were no ventilation fans and the doors and windows of the departments were open. To reduce the temperature in the mills, solutions such as ventilation or misting might be used.

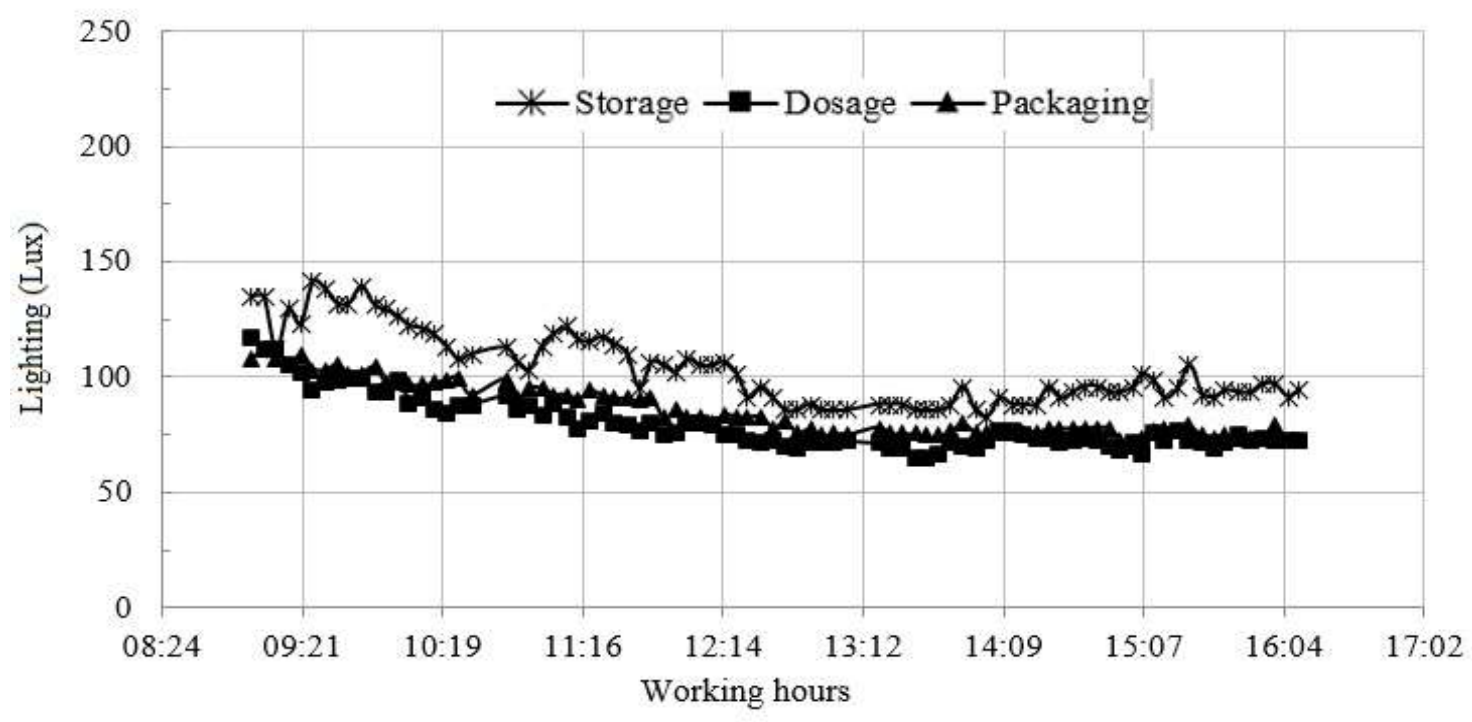

Figure 4. Average illumination values in working sections of feed mills

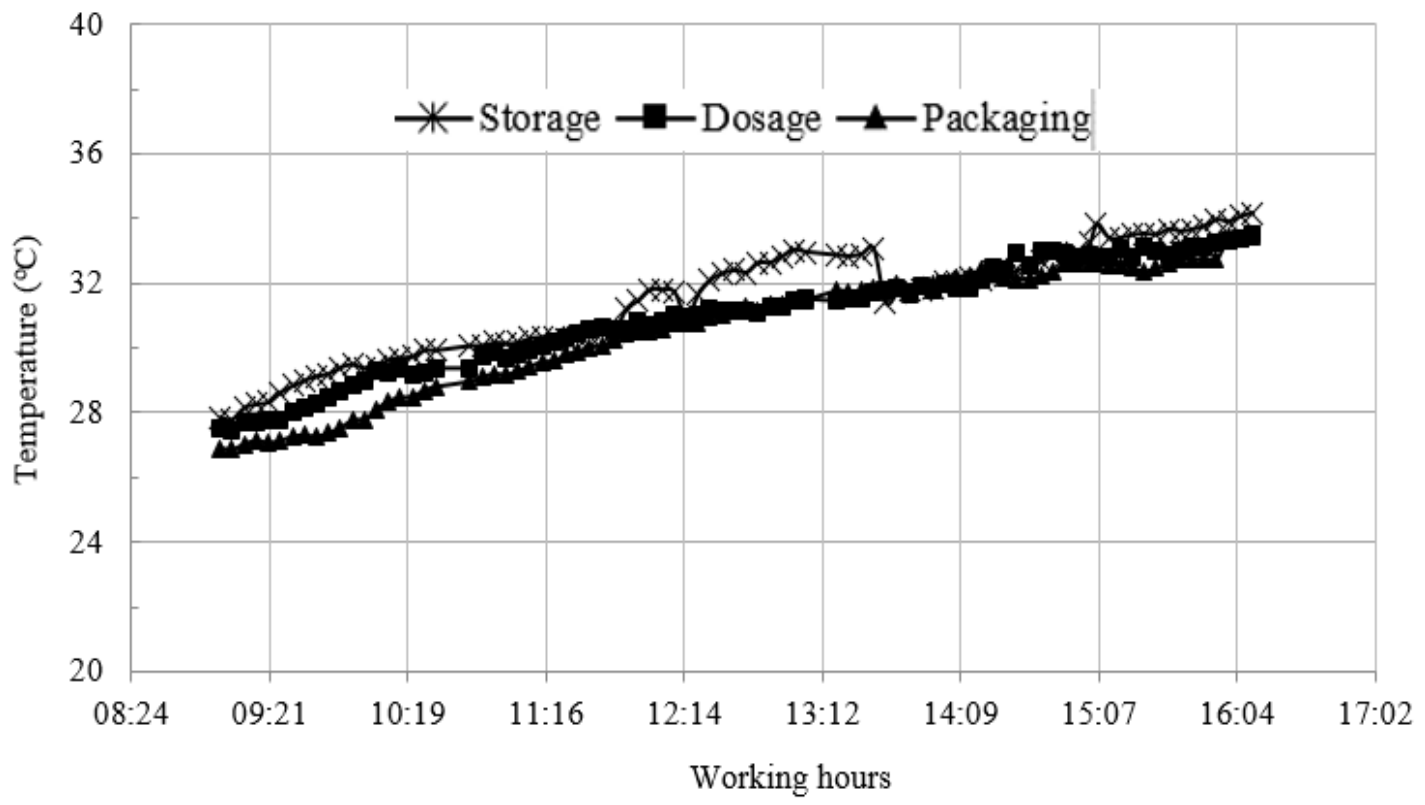

Figure 5. Average temperature values in working sections of feed mills

\section{Relative humidity}

The measured average $\mathrm{RH}$ values are given in Figure 6. The $\mathrm{RH}$ was relatively high early in the morning, but was not greater than $60 \%$. The highest $\mathrm{RH}$ was measured at the packaging section of mill $\mathrm{C}(63.7 \%)$, which was lower than the recommended upper limit for thermal comfort (70\%). The lowest RH was measured in the dosage section of mill B (15.4\%), which was lower than the lower limit value (30\%). In packaging section, the $\mathrm{RH}$ dropped below 30\% at about 2:00 pm whereas $\mathrm{RH}$ dropped to the lower limit
(30\%) at noon. The average $\mathrm{RH}$ in storage, dosage, and packaging departments were respectively 29\%, $31 \%$ and $38 \%$. Although the overall average of the relative humidity suggests thermal comfort, $\mathrm{RH}$ was out of the comfort zone after $1.00 \mathrm{pm}$. In addition, the combined effect of low humidity and physical and mental load of workers towards the end of the day might adversely affect the workers' efficiency. It could be concluded that, in the Mediterranean region, feed mills without air-conditioning will not provide conducive working environment in terms of relative 
humidity in the afternoons. Eventually, the workers were exposed to low $\mathrm{RH}$ for half of their working time in the storage and dosage sections and these sections need to be air-conditioned, particularly afternoon. It was concluded that, according to the recommended RH values (30-70\%) for thermal comfort (Suggs 1991; Tasyurek 2002), the average $\mathrm{RH}$ values were appropriate only in the morning for the dosage and packaging departments. Aybek et al. (2010) determined the average $\mathrm{RH}$ to be $41 \%$ in the storage, $51 \%$ in the dosage, and $44 \%$ in the packaging departments in earlier months. Therefore, the temperature and $\mathrm{RH}$ should be monitored and conditioned as needed.

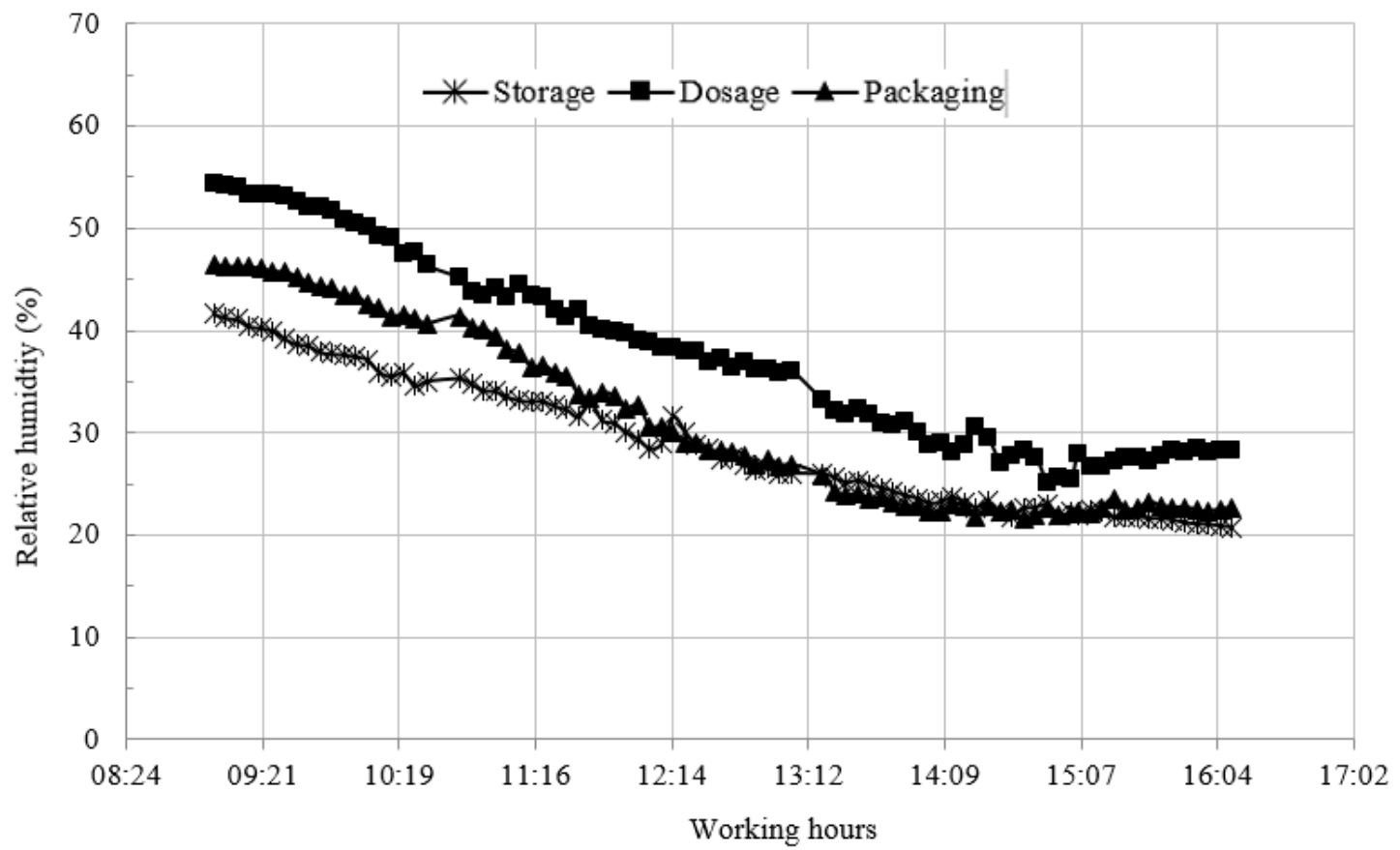

Figure 6. Average relative humidity values in working sections of feed mills

Air speed

The average air speed values measured in the feed mills are given in Figure 7. The average air speed varied between 0.6 and $0.9 \mathrm{~ms}^{-1}$. The average air speeds were found to be $0.89,0.77$ and $0.68 \mathrm{~ms}^{-1}$ in storage, dosage, and packaging departments, respectively. Aybek et al. (2010) found lower air speed values in another study with $0.09 \mathrm{~ms}^{-1}$ in storage section, $0.04 \mathrm{~ms}^{-1}$ in dosage section, $0.11 \mathrm{~ms}^{-1}$ in packaging section.

The highest air speed was measured at the dosage section of mill B $\left(2.48 \mathrm{~ms}^{-1}\right)$ whereas there were very low air speeds at the storage and dosage sections of mill A, dosage and packaging sections of mill $\mathrm{B}$, and storage and dosage sections of mill C. In Eastern Mediterranean region, wind starts blowing or increases its velocity in the afternoon and is usually effective until late night or next morning. The trend in measured wind speeds in the feed mills should be related to the climate in the region since there was no air-conditioning in the mills and the doors and windows are usually kept open in the summer season.

Air speed range was recommended to be $0.8-1.9 \mathrm{~ms}^{-1}$ for workers health (Suggs 1991). Based on this criterion, the average air speed values measured in storage departments of the feed mills were appropriate for thermal comfort, but were inappropriate in the dosage and packaging sections.

As a result, the same sections of different feed mills did not necessarily show the same results for the measured parameters. For instance, the average ambient temperatures in the packaging section of mill $\mathrm{A}$ and mill $\mathrm{C}$ were 30.7 and $28.6{ }^{\circ} \mathrm{C}$, respectively, suggesting thermal comfort for mill $\mathrm{C}$ and discomfort for mill A for the same working section (Table 2).

To make a generalized conclusion of the current study, it might be suggested that air conditioning should be done in the feed mills to obtain better environmental conditions for workers' health and efficiency. Official approval of the establishment of such facilities should be done following proper inspection of the investment projects in terms of preventions to reduce exposure levels of PM, temperature, relative humidity, noise, and lighting. Most of mills are likely to lack proper air conditioning and preventions against physical risk factors in Turkey. Therefore, governmental policies should require preventions for workers' safety and health during the installations of feed mills. Aeration and lighting could be improved in the current facilities at relatively low costs and exposure to PM could be reduced further by using personal preventions when needed. Similarly, noise reduction at the sources of 
the noise may not be cost-effective in a factory that is already in operation, however, personal noise exposure can be reduced easily in the range of 10-25
$\mathrm{dB}(\mathrm{A})$ by using ear plugs, which would eliminate the disturbances and potential hearing damages at the work place.

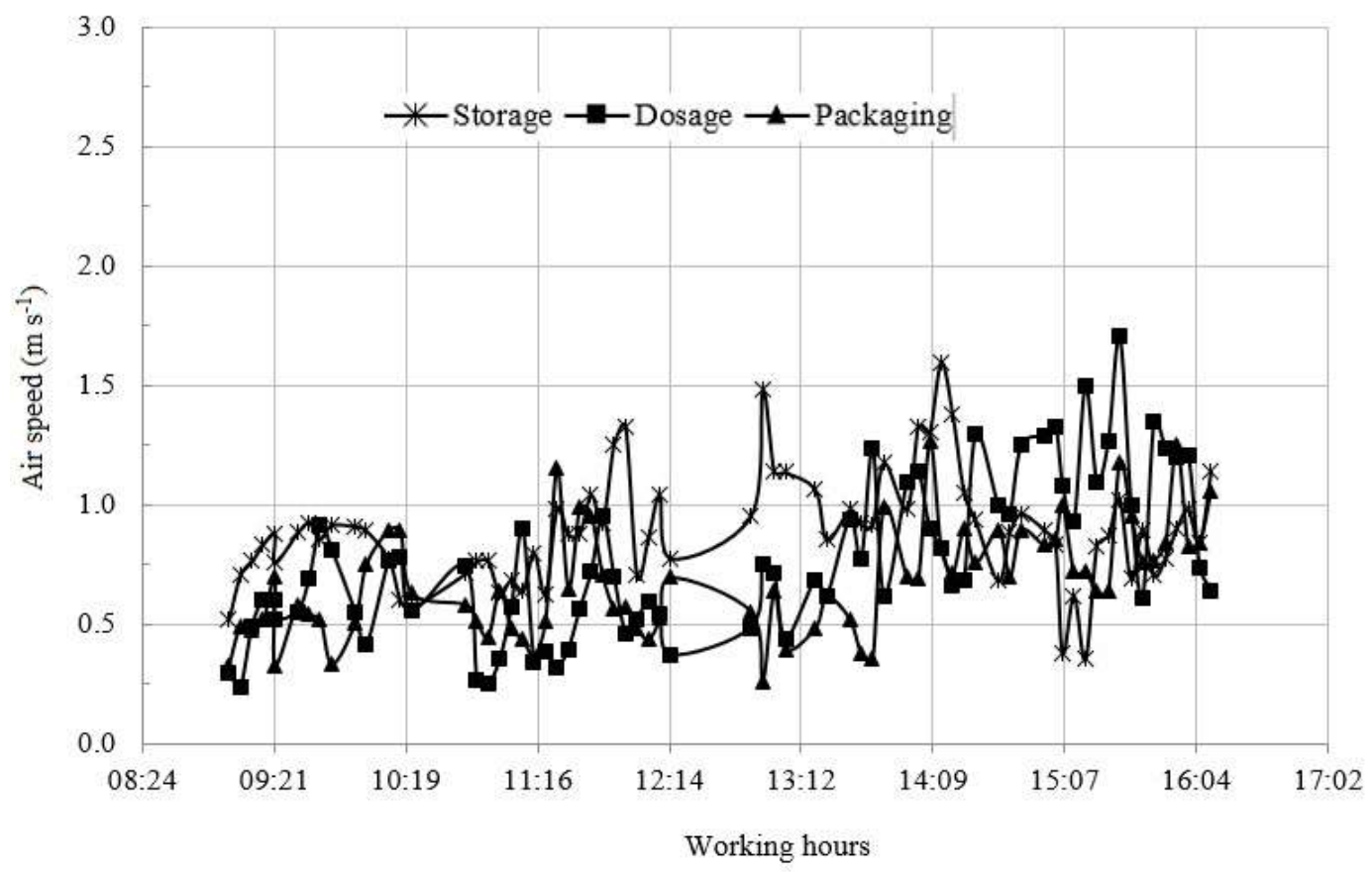

Figure 7. Average air speed values in working sections of feed mills

\section{Statistical analysis of ambient conditions}

The mean comparison test results are given in Table 3 , showing the statistical differences among the sections of each mill. The differences of three separate sections of feed mills were determined through Tukey test at 5\% significance level.

The ambient air temperatures at the three work sections of mill $\mathrm{A}$ and $\mathrm{C}$ were statistically different. The average temperatures varied from 29.8 to $30.7^{\circ} \mathrm{C}$ in mill A and 28.6 to $33^{\circ} \mathrm{C}$ in mill C. The difference between the smallest and greatest temperatures was about $1^{\circ} \mathrm{C}$ and $4.5^{\circ} \mathrm{C}$, respectively in mill $\mathrm{A}$ and $\mathrm{C}$. For practical purposes, the temperatures were in the same range in all sections of mill A while the temperature differences in the different sections of mill $\mathrm{C}$ show more differentiable differences to the workers. In general, the sections of both mill A and B showed small absolute differences. Mill B had two mean groups with the storage and dosage sections in the same statistical group.

The $\mathrm{RH}$ levels were in the same statistical mean group for storage and dosage sections in mills A and B whereas each section of mill $\mathrm{C}$ was in a different mean group. Similar observations could be done on air speed and lighting values. The average air speed was the same in the storage and the packaging sections in mill A while the dosage and packaging sections of mill B were in the same group, and all sections of mill $\mathrm{C}$ were different (Table 3). There were no statistical differences in the mean values of $\mathrm{RH}$ in storage and dosage sections of mill $\mathrm{A}$. The same result was found for factor $B$ whereas the three sections of mill C had different levels of RH statistically.

The wind speed in the different departments of mills were not statistically the same in any of the mills (Table 3).

The lowest (35.5 lux) and highest (186.6 lux) lighting values were found in the packaging section of mill $\mathrm{A}$. The very large difference in the lowest and highest lighting suggests poor lighting in the work environment. As a result the mean differences were significant between the storage section and dosage section as well as storage and packaging sections. The measured average lighting doubled in the dosage section of B (109.02 lux) compared to A (58.94 lux), suggesting that no standards were followed for lighting in these facilities.

The overall averages for temperature, humidity, air speed, and lighting $31.5{ }^{\circ} \mathrm{C}, 29.0 \%, 0.89 \mathrm{~ms}^{-1}$, and 103.4 lux, respectively in the storage section; $31.0{ }^{\circ} \mathrm{C}$, $31.1 \%, 0.77 \mathrm{~ms}^{-1}$, and 79.6 lux in the dosage section, and $30.6{ }^{\circ} \mathrm{C}, 37.7 \%, 0.68 \mathrm{~ms}^{-1}, 85.1$ lux in the packaging section (Table 2). In mill $\mathrm{B}$, there was no statistical difference in measured lighting values among the sections. 
Table 2. Measured values of the physical environmental factors in different sections of the feed mills

\begin{tabular}{|c|c|c|c|c|c|c|c|c|c|c|c|c|c|c|c|c|c|c|}
\hline & & & $\mathrm{A}$ & & & & & $\mathrm{B}$ & & & & & $\mathrm{C}$ & & & & & - Overall \\
\hline Physical factors & Sections & $\begin{array}{l}\text { No. of } \\
\text { samples }\end{array}$ & Ave. & $\begin{array}{l}\text { Std. } \\
\text { dev. }\end{array}$ & $\begin{array}{l}\text { Std. } \\
\text { error }\end{array}$ & Min. & Max. & Ave. & $\begin{array}{l}\text { Std. } \\
\text { dev. }\end{array}$ & $\begin{array}{l}\text { Std. } \\
\text { error }\end{array}$ & Min. & Max. & Ave. & $\begin{array}{l}\text { Std. } \\
\text { dev. }\end{array}$ & $\begin{array}{l}\text { Std. } \\
\text { error }\end{array}$ & Min. & Max. & $\begin{array}{l}\text { average of } \\
\text { the plants }\end{array}$ \\
\hline \multirow{3}{*}{$\begin{array}{l}\text { Ambient } \\
\text { temperature } \\
\left({ }^{\circ} \mathrm{C}\right)\end{array}$} & Storage & 84 & 29.79 & 2.08 & 0.23 & 26.3 & 33 & 31.60 & 1.66 & 0.18 & 28.2 & 34.6 & 33.03 & 1.93 & 0.21 & 28.9 & 36.5 & 31.47 \\
\hline & Dosage & 84 & 31.43 & 1.86 & 0.20 & 28.6 & 34.7 & 31.46 & 1.54 & 0.17 & 28.1 & 33.9 & 30.01 & 1.94 & 0.21 & 25.6 & 32 & 30.97 \\
\hline & Packaging & 84 & 30.66 & 1.56 & 0.17 & 27.6 & 32.6 & 32.58 & 1.85 & 0.20 & 28.8 & 34.8 & 28.57 & 2.60 & 0.28 & 24.1 & 34.2 & 30.60 \\
\hline \multirow{3}{*}{$\begin{array}{l}\text { Relative } \\
\text { humidity } \\
(\%)\end{array}$} & Storage & 84 & 29.29 & 5.91 & 0.64 & 21.6 & 39.4 & 27.53 & 6.07 & 0.66 & 19.8 & 37.8 & 30.05 & 7.83 & 0.85 & 20.5 & 47.8 & 28.96 \\
\hline & Dosage & 84 & 29.82 & 8.18 & 0.89 & 18.4 & 41.6 & 28.43 & 10.98 & 1.20 & 15.4 & 47 & 34.88 & 7.81 & 0.85 & 25.3 & 50.9 & 31.05 \\
\hline & Packaging & 84 & 33.29 & 7.58 & 0.83 & 23.8 & 48.3 & 35.73 & 9.12 & 1.00 & 21.1 & 51.5 & 44.15 & 11.78 & 1.29 & 27.1 & 63.7 & 37.72 \\
\hline \multirow{3}{*}{$\begin{array}{l}\text { Air speed } \\
\left(\mathrm{ms}^{-1}\right)\end{array}$} & Storage & 70 & 0.63 & 0.43 & 0.05 & 0 & 1.88 & 1.09 & 0.47 & 0.06 & 0.22 & 2.32 & 0.97 & 0.38 & 0.05 & 0 & 1.71 & 0.89 \\
\hline & Dosage & 70 & 0.95 & 0.47 & 0.06 & 0 & 1.9 & 0.88 & 0.52 & 0.06 & 0 & 2.48 & 0.49 & 0.42 & 0.05 & 0 & 1.82 & 0.77 \\
\hline & Packaging & 70 & 0.58 & 0.34 & 0.04 & 0 & 2 & 0.75 & 0.52 & 0.06 & 0 & 2.42 & 0.72 & 0.34 & 0.04 & 0.21 & 2.12 & 0.68 \\
\hline \multirow{3}{*}{ Lighting (lux) } & Storage & 84 & 138.92 & 16.74 & 1.83 & 106 & 186.6 & 102.30 & 35.50 & 3.87 & 67 & 177 & 68.93 & 11.58 & 1.26 & 51.2 & 96.2 & 103.38 \\
\hline & Dosage & 84 & 58.94 & 9.61 & 1.05 & 43.4 & 78.8 & 109.02 & 109.83 & 11.98 & 74.3 & 1094 & 82.60 & 13.53 & 1.48 & 61.9 & 135 & 79.62 \\
\hline & Packaging & 84 & 54.53 & 12.12 & 1.32 & 35.5 & 75 & 88.41 & 6.16 & 0.67 & 78.5 & 105 & 112.41 & 19.05 & 2.08 & 82.8 & 155 & 85.12 \\
\hline
\end{tabular}


Table 3. The significance test results of the physical factors measured in each section of the feed mills

\begin{tabular}{|c|c|c|c|c|c|}
\hline & & & $\mathrm{A}$ & B & $\mathrm{C}$ \\
\hline Physical factors & Section & $\begin{array}{l}\text { No. of } \\
\text { samples }\end{array}$ & $\begin{array}{l}\text { Ave. } \\
\pm \text { Std. error }\end{array}$ & $\begin{array}{l}\text { Ave. } \\
\pm \text { Std. error }\end{array}$ & $\begin{array}{l}\text { Ave. } \\
\pm \text { Std. error }\end{array}$ \\
\hline \multirow{3}{*}{$\begin{array}{l}\text { Ambient } \\
\text { temperature } \\
\left({ }^{\circ} \mathrm{C}\right)\end{array}$} & Storage & 84 & $29.79 \pm 0.23 c$ & $31.60 \pm 0.18 b$ & $33.03 \pm 0.21 \mathrm{a}$ \\
\hline & Dosage & 84 & $31.43 \pm 0.20 \mathrm{a}$ & $31.46 \pm 0.17 \mathrm{~b}$ & $30.01 \pm 0.21 \mathrm{~b}$ \\
\hline & Packaging & 84 & $30.66 \pm 0.17 \mathrm{~b}$ & $32.58 \pm 0.20 \mathrm{a}$ & $28.57 \pm 0.28 \mathrm{c}$ \\
\hline \multirow{3}{*}{$\begin{array}{l}\text { Relative } \\
\text { humidity } \\
\text { (\%) }\end{array}$} & Storage & 84 & $29.29 \pm 0.64 b$ & $27.53 \pm 0.66 \mathrm{~b}$ & $30.05 \pm 0.85 c$ \\
\hline & Dosage & 84 & $29.82 \pm 0.89 b$ & $28.43 \pm 1.20 \mathrm{~b}$ & $34.88 \pm 0.85 b$ \\
\hline & Packaging & 84 & $33.29 \pm 0.83 \mathrm{a}$ & $35.73 \pm 1.00 \mathrm{a}$ & $44.15 \pm 1.29 \mathrm{a}$ \\
\hline \multirow{3}{*}{$\begin{array}{l}\text { Air speed } \\
\left(\mathrm{ms}^{-1)}\right.\end{array}$} & Storage & 70 & $0.63 \pm 0.05 \mathrm{~b}$ & $1.09 \pm 0.06 \mathrm{a}$ & $0.97 \pm 0.05 \mathrm{a}$ \\
\hline & Dosage & 70 & $0.93 \pm 0.06 \mathrm{a}$ & $0.88 \pm 0.06 \mathrm{~b}$ & $0.49 \pm 0.05 c$ \\
\hline & Packaging & 70 & $0.58 \pm 0.04 \mathrm{~b}$ & $0.75 \pm 0.06 \mathrm{~b}$ & $0.72 \pm 0.04 \mathrm{~b}$ \\
\hline \multirow{3}{*}{$\begin{array}{l}\text { Lighting } \\
\text { (Lux) }\end{array}$} & Storage & 84 & $138.92 \pm 1.83 \mathrm{a}$ & $102.30 \pm 3.87 \mathrm{a}$ & $68.93 \pm 1.26 \mathrm{c}$ \\
\hline & Dosage & 84 & $58.94 \pm 1.05 \mathrm{~b}$ & $109.02 \pm 11.98 \mathrm{a}$ & $82.60 \pm 1.48 \mathrm{~b}$ \\
\hline & Packaging & 84 & $54.53 \pm 1.32 \mathrm{~b}$ & $88.41 \pm 0.67 \mathrm{a}$ & $112.41 \pm 2.08 \mathrm{a}$ \\
\hline
\end{tabular}

\section{CONCLUSION}

The following can be summarized and concluded as result of this study:

1. A weighted equivalent sound pressure levels in storage, dosage and packaging sections were 85 $\mathrm{dBA}, 84 \mathrm{dBA}$ and $86 \mathrm{dBA}$, respectively. Sound pressure levels at storage and packaging sections exceeded the highest exposure action value (85 $\mathrm{dBA}$ ) and exceeded the lowest exposure action value at the dosage section (80 dBA). Personal preventions should be considered in these facilities.

2. The greatest PM10, PM2.5, and PM1 concentrations were measured in the storage section with $2757 \mu \mathrm{g} \mathrm{m}^{-3}, 308 \mu \mathrm{g} \mathrm{m}^{-3}$, and $80 \mu \mathrm{g} \mathrm{m}^{-}$ ${ }^{3}$, respectively. PM10 exceeded the limit value $\left(2500 \mu \mathrm{g} \mathrm{m}^{-3}\right)$ requiring prevention from coarse dust in the storage section.

3 . The average daily lighting values in storage and packaging sections were respectively 103,80 , and 85 lux. Lighting levels in storage sections were between the recommended limit values (50 to 200 lux) whereas the measured values were below the recommended limit values (200 to 250 lux) in dosage and packaging sections. Artificial lighting should be provided in dosage and packaging sections.

4. The average temperatures in storage, dosage, and packaging sections were $30{ }^{\circ} \mathrm{C}$, which were above the limit values $\left(22\right.$ to $29^{\circ} \mathrm{C}$ ) accepted for thermal comfort zone of employees. Therefore, temperature was not suitable for comfortable working and should be controlled for better worker efficiency.

5. The average relative humidity in storage, dosage and packaging sections were $29 \%, 31 \%$ and $37 \%$, respectively. The measured values at dosage and packaging sections were within the recommended values for comfortable working (\% 30-70) and outside the recommended range in the storage sections.

6. The average air speed values in storage, dosage, and packaging sections were respectively 0.89 , 0.77 and $0.68 \mathrm{~ms}^{-1}$. The average air speed values in storage sections were within the recommended values $\left(0.8-1.9 \mathrm{~ms}^{-1}\right)$.

7. It could be recommended that air conditioning should be done, especially to control the ambient temperature in the working sections of the feed mills to ease the thermal stress the workers are being exposed to.

\section{ACKNOWLEDGEMENTS}

We thank the plant executives for cooperating with the researchers and KSU Scientific Research Projects Management Unit for supporting the study.

\section{REFERENCES}

Ahmed AH, Bilal IE, Merghani TH 2009. Effects of exposure to flour dust on respiratory symptoms and lung function of bakery workers: a case control study. Sudanese Journal of Public Health 4(1): 210-213.

Arıcı K 1999. Worker Health and Safety, Sargin Ofset, Ankara. pp. 178s. (In Turkish)

Aybek A, Arslan S 2005. Noise measurements in agriindustrial facilities in Turkey. KSU. Journal of Science and Engineering 8(2): 121-127.

Aybek A, Arslan S, Ekerbiçer H 2010. Assessment of particulate matter exposure and associated health 
risks in agriculture and agri-industry. Final Report. TÜBİTAK-TOVAG-1070513, Ankara.

Babalık FC 2007. Ergonomics for Engineers. Texbook. Nobel Yayın Dağıtım Ltd. Şti. 2nd Edition, No: 831, Ankara. 96 p.

Başpinar N, Bayramlı Ü 2006. Office Management, 2nd Edition, Nobel Yayın Dağıtım. Ankara. 178 p. (In Turkish)

Ege F, Sümer SK, Sabancı A 2003. Noise levels in textile mills and its effects. In Proc. $2^{\text {nd }}$ Occupational Health and Safety Congress p 76.

EU Directive 1999. Limit values for sulphur dioxide, nitrogen dioxide and oxides of nitrogen, particulate matter and lead in ambient air. Council Directive 1999/30/EC. Official Journal of the European Communities.

EU Directive 2003. Use of Personal Protective Equipment. Directive 89/656/EEC. https://osha. europa.eu/en/legislation/directives/4. Accessed 02.03.2016.

Giri D, Murthy VK, Adhikary PH, Khanal PN 2007. Estimation of number of deaths associated with exposure to excess ambient PM10 air pollution. Int. J. Environ. Sci. Tech., 4(2): 183-188.

Hayta AB 2007. The effect of the working environment conditions to management fertility. Journal of Commerce \& Tourism Education Faculty 1:21-41s. (Abstr. in English)

İçin D 2011. Personal Exposure to Noise in Flour, Feed and Oil Mills. MSc Thesis. Kahramanmaraş Sütçü Imam University, Graduate School of Natural and Applied Sciences. KahramanmaraşTurkey.

Ilicak Ş 1988. Environment-Work Conditions and Ergonomic Approaches. 1st National Ergonomics Congress, National Productivity Center Productions, No: 372, Ankara. (In Turkish)

Matthews J, Knight AA 1971. Ergonomics in Agricultural Equipment Design. National Institute of Agricultural Engineering, Silsoe.

Sabanc1 A 2001. Occupational Health-SafetyErgonomics. In Proceeding of Occupational Health and Safety Congress. Adana. pp. 281-295. (In Turkish)

Sabanc1 A, Sümer SK 2015. Ergonomics, Nobel Akademik Yayıncılık Eğitim Danışmanlık Tic. Ltd Şti. Ankara (In Turkish)

Şerefhanoğlu Sözen M, İlgürel N, Erdoğan S 2008. Development of a method to use noise as a criteria in design process of industrial buildings. Research Project Report, TÜBİTAK Project No: 105M233. 79 p.

Sprince NL, Lewis MQ, Whitten PS, Reynolds SJ, Zwerling C 2000. Respiratory symptoms: associations with pesticides, silos and animal confinement in the Iowa Farm Family Health and Hazard Surveillance Project. American Journal of Industrial Medicine, 38:455-462.

Suggs CW 1991. Thermal Environment of Agricultural Workers, Environmental Stress. Module 10. ASAE, St. Joseph Michigan. 22p.

Tasyürek M 2002. Occupational Health Safety. Work Environment Journal, 61:9-11 (In Turkish)

Tayyari F, Smith, JL 1997. Occupational Ergonomics Principles and Application, Chapman \& Hall, First Ed., London. 81p.

TS 2607 ISO 1999. Acoustics - Determination of occupational noise exposure and estimation of noise-induced hearing impairment.

TS EN ISO 9612 2009. Akustik-Mesleki Gürültü Maruziyetinin Belirlenmesi Mühendislik Metodu

Wilson JR, Corlett N 1991. Evaluation of Human Work, Taylor \& Francis Ltd., 2nd Ed., London. $53 \mathrm{p}$.

Witney B 1988. Choosing and Using Farm Machines. Co-published in the United States with John Wiley\&Sons Inc., Newyork. 412p. 